\title{
Knowledge or ignorance about correct use of inhalers among physicians in Primary Health Care Centers in Serbia
}

\author{
Marina B. Fišeković Kremić \\ Primary Health Care Centre New \\ Belgrade, Belgrade, Serbia
}

Primljen - Received: 01/04/2020

Prihvaćen - Accepted: 01/12/2020

\author{
Corresponding author: \\ Marina B. Fišeković Kremić, PhD \\ Djordja Čutukovića 48a/6, \\ 11080 Zemun, Belgrade, Serbia, \\ marina.b.fisekovic@gmail.com
}

Copyright: @2020 Marina B. Fišeković Kremić. This is an Open Access article distributed under the terms of the Creative Commons Attribution 4.0 International (CC BY 4.0) license.

\begin{abstract}
Introduction. In daily use, a large majority of patients make inhalation errors. Primary health care doctors have an important role in preventing improper use of inhalers. The aim of this study is to evaluate the level of knowledge regarding the correct use of inhalers among physicians who work in primary health care centers as well as to evaluate the method of acquiring knowledge regarding an adequate inhalation technique.
\end{abstract}

Methods. The research belonged to a cross sectional study, conducted on March 2019., in Belgrade, Serbia. The sample consisted of physicians who work in primary health care centers in Serbia. The data were collected by means of a questionnaire. The results were shown by parameters of descriptive statistics. The difference in the number of points among the two groups and other variables were tested by means of X2 test. The data were analyzed using SPSS 20.

Results. The survey included 364 physicians in primary health care. $86.5 \%$ of them were female respondents. The mean work experience was $19 \pm 11.22$ years. In half of respondents family medicine was the scope of specialty (53\%). The majority of respondents acquired knowledge about the correct use of inhalers by participating in lectures and workshops (50.3\%). It was found that the physicians possessed an unsatisfactory level of knowledge.

Conclusion. Primary health care physicians possess inadequate knowledge and skills concerning the proper use of inhalers. Lectures and workshops are not sufficient enough to educate doctors concerning the use of inhalers.

Keywords: inhalers, knowledge, education, general practice

\section{Introduction}

Asthma and chronic obstructive pulmonary disease (COPD) are one of the main public health problems $[1,2]$. Inhalers play a key role in maintaining disease control in asthma and chronic obstructive pulmonary disease patients. COPD is currently the fourth leading cause of death in the world but is projected to be the 3rd leading cause of death by 2030. COPD burden is projected to increase in coming decades because of continued exposure to COPD risk factors and population aging. The lowest estimates of prevalence are those based on self-reporting of a doctor's diagnosis of COPD, or equivalent condition. Prevalence of COPD grade 2 or higher of $10.1 \%$ overall, $11.8 \%$ for men, and 
$8.5 \%$ for women, and a substantial prevalence of COPD of $3-11 \%$ among never-smokers [3,4].

Inhalers can be divided into three groups: pressurised metered dose inhalers (MDIs), dry powder inhalers (DPIs) and nebulisers. Adherence to prescribed treatment is necessary to ensure achievement of therapeutic effect. Inhaled therapy requires patients' acceptance and successful mastery of the inhaler technique specific to their device(s). The aim of inhaled therapy is to deliver drug directly to the lungs, thereby offering a more rapid onset of action and a lower required dose than systemic administration, minimizing the potential adverse effects. The important cause of poor control is improper inhaler technique, since no matter how good a drug is, it cannot be effective unless it reaches the targeted airways [5]. In daily use, a large majority of patients make inhalation errors [4,6]. It is associated with worsened health outcomes, poor disease control and increased risk of hospitalization [6,7]. Consequences can also be found in the financial context of considerable amount of resources spent on inhalers [8]. It is of utmost importance to properly train patients where inhaler technique is concerned $[7,9]$.

Doctors of primary health care have an important role in preventing improper use of inhalers in patients. Nowadays, new types of inhalers are continually being developed, which on the one hand allows for adequate choice of therapy according to the individual needs, while on the other hand presents a challenge, as doctors need to be familiar with their characteristics.

The aim of this study is to evaluate the level of knowledge regarding the correct use of inhalers among physicians who work in primary health care centers as well as to evaluate the method used for acquiring knowledge regarding adequate inhalation technique.

\section{Methods}

The research belonged to cross sectional study, conducted on March 2019., at the General Medicine Conference in Belgrade. The sample consisted of all present physicians who were presented with the questionnaire at the registration. The physicians who work in Primary Health Care (PHC) Centers, general practitioners (physicians without specialization) and family medicine physicians (physicians with specialization) attended the conference. The total number of physicians in the PHC centers in Serbia was 3820, out of which 1877 were general practitioners and 1943 family medicine physicians, according to the database of the Institute of Public Health of Belgrade [10]. The data were collected by means of a questionnaire, which doctors filled out voluntary. The questionnaire was used earlier, in the research conducted in primary health care [11].

The questionnaire consisted of 11 questions: first 4 items concerning the personal and workplace data (gender, age, years of service, professional competence); and 7 items concerning the method of acquiring knowledge about inhalers and implementing education of patient on the proper use of inhalers. The questions belonged to the class of "multiple choice questions".

The level of physicians' knowledge and their attitude towards the proper use of the inhaler were assessed by summing up the correct answers to the questions: 1 . Correct use of metered dose inhale (MDI); correct answer (slowly inhale and at the same time activate the inhaler); 2 . Correct use of dry powder inhale (DPI); (breathe strong, deeply and quickly); 3 . Which factor is most important when choosing a patient's inhaler? (patient's preference); 4 . After prescribing the inhaler, does you or someone else educate patients about its use? (always). One point was added for each correct answer. By summing the points obtained, (a range of 0-4), the respondents were divided into two groups concerning the proper use of inhalers: the ones with an unsatisfactory level of knowledge $(\leq 2)$ and the ones with satisfactory level of knowledge $(\geq 3)$.

The descriptive statistics was compiled for the entire population sample. The difference in the number of points of the two groups (specialist or non-specialist) and other variables were tested with the $\mathrm{X}^{2}$ test. The difference in the achieved 
number of points in relation to the groups of respondents was assessed by the Mann Whitney test. The data were analyzed using SPSS 20. The results were considered to be statistically significant when the P value was $\leq 0.05$.

\section{Results}

The survey covered 364 physicians of PHC. Out of the total, $86.5 \%$ of respondents were female. The mean age of the participants was $48 \pm 10.64$ years. The mean work experience was $19 \pm 11.22$ years. The half of respondents had family medicine as their scope of expertise (53\%).

The majority of respondents acquired knowledge about the correct use of inhalers by partici- pating in lectures and workshops (50.3\%). More than two thirds of the respondents had experience in prescribing inhalers (87.6\%). When asked about the most important step for correct use of MDI, 156 (42.9\%) respondents selected the correct answer, while $73(20.1 \%)$ respondents gave appropriate answer where the correct use of DPI was concerned. Most of respondents, i.e. 326 $(89.6 \%)$ of them, pointed out the type of disease as the most important factor in selecting a patient's inhaler. The respondents did not consider patient's preferences as important in the selection of inhalers, apart from three physicians. Usually, the education of patients when prescribing the inhaler was carried out by $49.5 \%$ of physicians. Most physicians personally carry out the educa-

Table 1. Respondents' answers concerning proper use and prescription of inhalers

\begin{tabular}{|c|c|}
\hline Variable & $\mathrm{N}(\%)$ \\
\hline \multicolumn{2}{|l|}{ You have acquired the knowledge about the use of inhalers by: } \\
\hline Participating in lectures and workshops & $183(50.3)$ \\
\hline Using professional literature & $70(19.2)$ \\
\hline Using drug instruction & $52(1.3)$ \\
\hline From experience & $59(16.2)$ \\
\hline Have you ever prescribed an inhaler? & $319(87.6)$ \\
\hline $\begin{array}{l}\text { Correct use of metered dose inhale (MDI): } \\
\text { Slowly inhale and at the same time activate the inhaler }\end{array}$ & $156(42.9)$ \\
\hline $\begin{array}{l}\text { Correct use of dry powder inhale (DPI): } \\
\text { Breathe strong, deeply and quickly }\end{array}$ & $73(20.1)$ \\
\hline \multicolumn{2}{|l|}{ The most important factor when choosing a patient's inhaler } \\
\hline Type of illness (asthma / COPD) & $326(89.6)$ \\
\hline Patient's preference & $3(0.8)$ \\
\hline Age of the patient & $15(4.1)$ \\
\hline Patient's previous experience with a particular inhaler & $20(5.5)$ \\
\hline \multicolumn{2}{|l|}{ After prescribing the inhaler, is a patient educated about its use? } \\
\hline Always & $180(49.5)$ \\
\hline Sometimes & $143(39.3)$ \\
\hline Almost never & $26(7.1)$ \\
\hline Never & $15(4.1)$ \\
\hline \multicolumn{2}{|l|}{ Who educates the patients in your healthcare clinic? } \\
\hline Only you & $203(55.8)$ \\
\hline A nurse & $41(11.3)$ \\
\hline Pharmacist in pharmacy & $66(18.1)$ \\
\hline Nobody, the patient is given an educational leaflet & $54(14.8)$ \\
\hline
\end{tabular}


Table 2. Differences between two observed groups of respondents in evaluated variables

\begin{tabular}{|c|c|c|c|}
\hline Variable N (\%) & Non- specialists & Specialists & $\mathrm{p}$ \\
\hline $\begin{array}{l}\text { Gender } \\
\text { Men } \\
\text { Women }\end{array}$ & $\begin{array}{l}27(15.8) \\
144(84.2)\end{array}$ & $\begin{array}{l}22(11.4) \\
171(88.6)\end{array}$ & 0.221 \\
\hline $\begin{array}{l}\text { Age } \\
\leq 29 \\
30-49 \\
50-59 \\
\geq 60\end{array}$ & $\begin{array}{l}20(11.7) \\
111(64.9) \\
33(19.3) \\
7(4.1) \\
\end{array}$ & $\begin{array}{l}0(0) \\
51(26.4) \\
100(51.8) \\
42(21.8)\end{array}$ & $<0.001$ \\
\hline $\begin{array}{l}\text { Work experience } \\
\leq 10 \\
11-20 \\
21-30 \\
31-40\end{array}$ & $\begin{array}{l}105(61.4) \\
35(20.5) \\
24(14.0) \\
7(4.1)\end{array}$ & $\begin{array}{l}5(2.6) \\
47(24.4) \\
84(43.5) \\
57(29.5)\end{array}$ & $<0.001$ \\
\hline $\begin{array}{l}\text { You have acquired the knowledge about the use of inhalers by: } \\
\text { Participating in lectures and workshops } \\
\text { Using professional literature } \\
\text { Using drug instruction } \\
\text { From experience }\end{array}$ & $\begin{array}{l}68(39.8) \\
45(26.3) \\
27(15.8) \\
31(18.1)\end{array}$ & $\begin{array}{l}115(59.6) \\
25(13.0) \\
25(13.0) \\
28(14.5)\end{array}$ & 0.001 \\
\hline Have you ever prescribed an inhaler? & $143(83.6)$ & $176(91.2)$ & 0.029 \\
\hline $\begin{array}{l}\text { The most important factor when choosing a patient's inhaler: } \\
\text { Type of illness (asthma / COPD) } \\
\text { Patient's preference } \\
\text { Age of the patient } \\
\text { Patient's previous experience with a particular inhaler }\end{array}$ & $\begin{array}{l}155(90.6) \\
1(0.6) \\
7(4.1) \\
8(4.7) \\
\end{array}$ & $\begin{array}{l}171(88.6) \\
2(1.0) \\
8(4.1) \\
12(6.2)\end{array}$ & 0.883 \\
\hline $\begin{array}{l}\text { After prescribing the inhaler, is a patient educated about its use? } \\
\text { Always } \\
\text { Sometimes } \\
\text { Almost never } \\
\text { Never }\end{array}$ & $\begin{array}{l}82(48.0) \\
69(40.4) \\
12(7.0) \\
8(4.7)\end{array}$ & $\begin{array}{l}98(50.8) \\
74(38.3) \\
14(7.3) \\
7(3.6)\end{array}$ & 0.921 \\
\hline
\end{tabular}

Table 3. Distribution of estimated knowledge level concerning an appropriate use of inhalers between two observed groups of respondents

\begin{tabular}{llll} 
Variable N $(\%)$ & Non- specialist & Specialists & $\mathrm{p}$ \\
\hline $\begin{array}{l}\text { Knowledge level concerning an } \\
\text { appropriate use of inhalers }\end{array}$ & & 0.336 \\
$\quad$ Unsatisfactory $(\leq 2)$ & $159(93.0)$ & $184(95.3)$ & \\
$\quad$ Satisfactory $(\geq 3)$ & $12(7.0)$ & $9(4.7)$ & \\
\hline
\end{tabular}

tion of patients (55.8\%), the less pharmacy in the pharmacy (18.1\%) (Table 1).

There were differences between two observed groups of respondents concerning years of age and work experience. The difference between general practitioner and family medicine physician respondents was in the mode of acquiring knowledge. Family medicine physicians acquired knowledge during lectures and workshops and prescribed independently more inhalers. There were no differences between two observed groups in gender and in items such as the most important factor when choosing a patient's inhaler and do you or any of your co-workers educate the patient after prescribing the inhaler (Table 2).

Physicians showed an unsatisfactory level of knowledge. The difference concerning the assessment of knowledge between two observed groups of respondents was not statistically significant $\left(X^{2}=0.92 ; p=0.336\right)$ (Table 3 ).

There was no difference in the score where different groups were concerned (Mann Whitney $z=-0.96 ; p=0.337$ ) (Figure 1). 


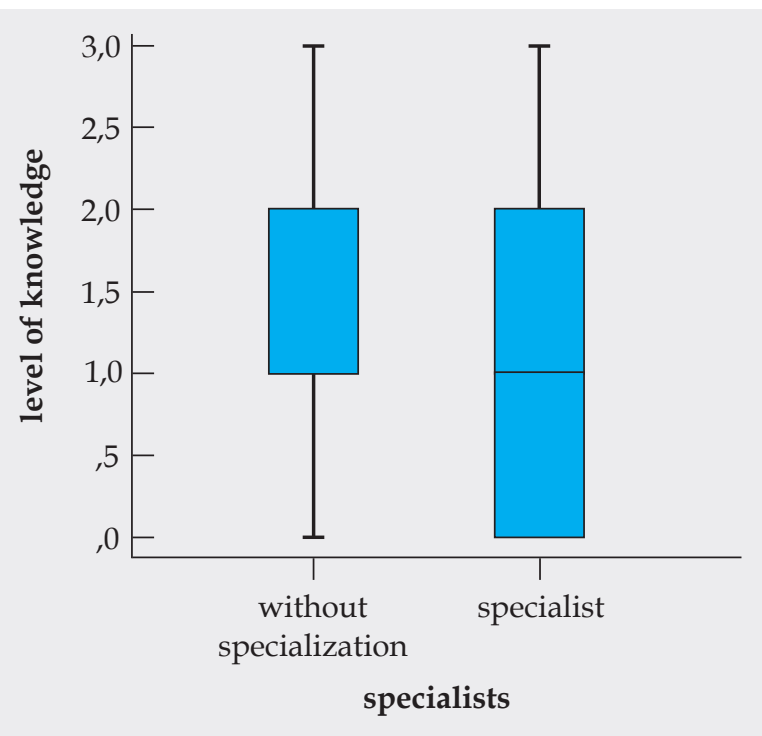

Figure 1. Level of knowledge acquired in two groups of respondents

\section{Discussion}

Recently, multiple studies have been carried out showing that health care professionals prescribe inhalers without enough knowledge concerning their use. Current guidelines on treating asthma/ COPD recommend that physicians demonstrate to patients how to use the different devices, but there is high percentage of health care professionals who are incapable of performing a simple demonstration where the correct use of the inhaler devices is concerned $[6,12,13]$. This lack of knowledge has not improved, despite efforts put in by education institutions. In the study, there were $90 \%$ of physicians who possessed an unsatisfactory knowledge about the correct use of the inhaler devices. The errors committed during inhaler use can reduce treatment effectiveness. Mishandling of inhalation devices decreases patient adherence to the inhaler therapeutic regimen, compromising treatment efficacy. A simple educational intervention delivered by general practices in primary health care should improve inhaler technique among patients. Outpatient education in inhaler technique remains widely inconsistent due to time-consuming inhalation training, limited resources, and inadequate doctor knowledge [14-16]. In British Columbia and Alberta, training session was arranged for general practitioners. Sessions were spaced out over 1-3 months. Prior to the program, only
$10 \%$ of doctors felt fully competent to teach inhaler technique, while after the program, $98 \%$ of them rated their teaching as satisfactory, and they could teach inhaler technique [17]. In our research, there was a difference in acquiring knowledge between specialist and non-specialist. Knowledge was mostly acquired during lectures and workshops, but doctors without specialization relied on more professional literature, drug instruction and experience. They were probably less overburdened and had more enthusiasm, strength and free time to devote themselves to other forms of acquiring knowledge.

Clinical evidence suggests that although contemporary inhaled therapy has the potential to control disease [12], it is often not achieved in practice. Poor inhaler technique is one of important reasons, because no matter how good a drug is, it cannot be effective unless it reaches the targeted airways $[5,9,18]$. There are more than 200 drug-inhaler device combinations that are available $[19,20]$. Braido and co-workers revealed that the MDI had the highest average frequency of errors, more than $40 \%$. It was expected that DPIs would make better performance but their error rates were only slightly lower than MDI rates [19]. Among our doctors, $43 \%$ of then knew how to use the MDI inhalers correctly, while approximately $20 \%$ of them possessed the correct knowledge concerning DPI. This explained the larger number of errors when the DPI inhalers were used.

Certain observational studies suggested that between $50 \%$ and $60 \%$ of patients misused a dry powder inhaler [21]. Some of the possible errors included inadequate flow (27\%), drug priming without inhalation (19\%), exhalation into the inhaler (18\%), and multiple inhalations (25\%). Out of 60 doses expected to be taken during a month per person, the average number of actual doses was $34(57 \%)$. According to Sulaiman and co-workers, an irregular inhaler use was common and only $20 \%$ of participants used their inhaler correctly [21].

Adherence to prescribed treatment is necessary to ensure the achievement of the therapeutic effect. In inhalation therapies, patients' permission is required and also the choice of the right inhaler for the right patients [18,19]. Among our 
respondents, only $3(0.8 \%)$ doctors accepted the patient's preference to choose the inhaler. This considerably contributed to our respondents having an unsatisfactory level of knowledge about the use of inhalers. However, it is common for patients undergoing prolonged treatment to have poor adherence to medication [22]. Patients' adherence to treatment can be influenced by their overall state of being, dosing frequency, their expectations regarding disease treatment, and to a great extent by the quality and ease of use of the device [23]. The idea is that involving the patient in the decision-making will result in enhancing patient satisfaction with the inhaler device, which in turn will lead to increased adherence and better clinical outcomes [23]. Moreover, the GINA guidelines suggest that patients would see more inhaler devices and participate in the decision concerning the best possible choice for them. [24]. However, not all of our general practitioners in Serbia are equipped with a placebo training inhalers.

Adherence to the therapy involves patients initiating their prescribed therapy, correct administration of the prescribed dose, and treatment persistence.

Due to certain limitations, the broader application of our study may be restricted. Since

Funding source. The authors received no specific funding for this work.

Ethical approval. The Ethics Committee of the Society of General Practice approved the study. Participation in the research was voluntary and informed consent was obtained from all individual respondents. Anonymity,

\section{References}

1. Fontana L, Lee SJ, Capitanelli I, Re A, Maniscalco M, Mauriello MC, et al. Chronic Obstructive Pulmonary Disease in Farmers. JOEM. 2017;59(8):775-88.

2. Jiang XQ, Mei XD, Feng D. Air pollution and chronic airway diseases: what should people know and do? J Thorac Dis. 2016;8(1):E31.

3. Global Strategy for the Diagnosis, Management, and Prevention of Chronic Obstructive Pulmonary Disease 2020 Report (Full Report). Global Initiative for Chronic Obstructive Lung Disease. 2019 Nov. Available from: www.goldcopd.org. Accessed: March 10, 2020. this is a cross sectional study, cause-and-effect relationships cannot be studied. There is also the possibility of recall biases from respondents when completing the questionnaire. The findings of this research are limited to physicians who work in primary health care centers. For better representation and associations, it is recommended for future studies to be carried including a larger number of samples.

\section{Conclusion}

In conclusion, primary healthcare physicians possess inadequate knowledge and skills concerning the proper use of inhalers. Lectures and workshops are not an adequate method for educating physicians about the use of inhalers. Physicians' education should be continuous and different models of education should be offered.

\section{Acknowledgement}

I would like to express my special thanks to doctors which took part in the research and spent their time to complete the questionnaires. Furthermore, I would like to thank the Society of General Practice for supporting this research and an administrative staff of the Serbian Medical Society.

confidentiality and privacy of data were explained and guaranteed. The research was conducted according to the Declaration of Helsinki.

Conflicts of interest. The author declare no conflicts of interest.

4. Burden of Obstructive Lung Disease Initiative [homepage on the Internet]. Imperial College London [updated Oct 2020]. Available from: http://www. boldstudy.org/ Accessed: March 10, 2020.

5. Levy ML, Hardwell A, Mcknight E, Holmes J. Asthma patients' inability to use a pressurized metered-dose inhaler ( $\mathrm{pMDI}$ ) correctly correlates with poor asthma control as defined by the Global Initiative for Asthma (GINA) strategy: a retrospective analysis. Prim Care Respir J 2013; 22 (4) pp. 406-11. 
6. Klijn SL, Hiligsmann M, Evers SM, Roman-Rodriguez M, van der Molen T, van Boven JF. Effectiveness and success factors of educational inhaler technique interventions in asthma \& COPD patients: a systematic review. NPJ Prim Care Respir Med 2017;27(1):24.

7. Melzer AC, Ghassemieh BJ, Gillespie SE, Lindenauer PK, McBurnie MA, Mularski RA, et al. Patient characteristics associated with poor inhaler technique among a cohort of patients with COPD. Respir Med 2017;123:124-30

8. Lewis A, Torvinen S, Dekhuijzen PN, Chrystyn H, Watson AT, Blackney M, et al. The economic burden of asthma and chronic obstructive pulmonary disease and the impact of poor inhalation technique with commonly prescribed dry powder inhalers in three European countries. BMC Health Serv Res 2016;16(1):251.

9. Sanchis J, Gich I, Pedersen S, Team AD. Systematic review of errors in inhaler use: has patient technique improved over time? Chest 2016;150(2):394-406.

10. Institute of Public Health of Serbia "Dr Milan Jovanovic Batut". Health statistical yearbook of Republic of Serbia 2018. Belgrade: Institute of Public Health of Serbia "Dr Milan Jovanovic Batut"; 2019.

11. Sambol K, Cikac T. Do we treat disease or the patient? Med Farm Croat 2017;25(1-2):27-34.

12. Wedzicha JA, Calverley PM, Albert RK, Anzueto A, Criner GJ, Hurst JR, et al. Prevention of COPD exacerbations: a European respiratory Society/American thoracic Society guideline. Eur Respir J 2017;50(3).

13. Fattah MT, Aziz AO, Aziz MO, Atta MI, Mounir SM, Amin SA. Prescription of inhalers among pulmonologists and non pulmonologists: is there a difference? Egypt J Bronchol 2017;11(4):301.

14. Koblizek V, Novotna B, Zbozinkova Z, Hejduk K. Diagnosing COPD: advances in training and practice-a systematic review. Adv Med Educ Pract 2016; 7:219.

15. Alzaye R, Chaar BB, Basheti IA, Saini B. General Practitioners' experiences of asthma management in culturally and linguistically diverse populations. J Asthma 2018; 10:1-1.
16. Ashraf M, Ullah E, Ahmed M, Zaidi AA, Zainab G, Muslim HM. Asthma care perceptions and practices among general practitioners at Bahawalpur. Pakistan J Chest Med 2015;13: 14(3).

17. Leung J, Bhutani M, Leigh R, Pelletier D, Good C, Sin DD. Empowering family physicians to impart proper inhaler teaching to patients with chronic obstructive pulmonary disease and asthma. Can Respir J 2015;22(5):266-70.

18. Abegaz TM, Shegena EA, Gessie NF, Gebreyohanns EA, Seid MA. Barriers to and competency with the use of metered dose inhaler and its impact on disease control among adult asthmatic patients in Ethiopia. BMC Pulm Med 2020; 20(1):1-3.

19. Braido F, Chrystyn H, Baiardini I, Bosnic-Anticevich S, van der Molen T, Dandurand RJ, et al. "Trying, but failing" - the role of inhaler technique and mode of delivery in respiratory medication adherence. J Allergy Clin Immunol Pract 2016;4(5):823-32.

20. Dhand R, Mahler DA, Carlin BW, Hanania NA, Ohar JA, Pinto-Plata V, et al. Results of a patient survey regarding COPD knowledge, treatment experiences, and practices with inhalation devices. Respir Care 2018;63(7):833-39.

21. Sulaiman I, Seheult J, MacHale E, D'Arcy S, Boland F, McCrory K, et al. Irregular and ineffective: a quantitative observational study of the time and technique of inhaler use. J Allergy Clin Immunol Pract 2016;4(5):900-9.

22. Plaza V, Giner J, Calle M, Rytilä P, Campo C, Ribó $\mathrm{P}$, et al. Impact of patient satisfaction with his or her inhaler on adherence and asthma control. Allergy Asthma Proc 2018; 39(6):437-44.

23. Ding B, Small M, Scheffel G, Holmgren U. Maintenance inhaler preference, attribute importance, and satisfaction in prescribing physicians and patients with asthma, COPD, or asthma-COPD overlap syndrome consulting for routine care. Int J Chron Obstruct Pulmon Dis 2018;13:927-36.

24. Boulet LP, Reddel HK, Bateman E, Pedersen S, FitzGerald JM, O'Byrne PM. The global initiative for asthma (GINA): 25 years later. Eur Respir J 2019;54(2):1900598. 


\section{Questionnaire}

1. Gender

Men Women

2. Age

3. Physician

a) non-specialist

b) specialist registrars

c) general practitioner

4. Work experience years

5. You have acquired the knowledge about the use of inhalers by:
a) Participating in lectures and workshops
b) Using professional literature
c) Using drug instruction
d) Personal experience

6. Have you ever prescribed an inhaler?

a) Yes b) No

7. Correct use of metered dose inhale (MDI):
a) Shake the inhaler hard
b) Breathe out all the way
c) Slowly inhale and at the same time activate the inhaler
d) Breathe strong, deeply and quickly
e) Continue slowly with deep inhalation

8. Correct use of dry powder inhale (DPI):
a) Shake the inhaler hard
b) Breathe out all the way
c) Slowly inhale and at the same time activate the inhaler
d) Breathe strong, deeply and quickly
e) Continue slowly with deep inhalation

9. The most important factor when choosing a patient's inhaler:
a) Type of illness (asthma / COPD)
b) Patient's preference
c) Age of the patient
d) Patient's previous experience with a particular inhaler

10. After prescribing the inhaler, do you or any of your co-workers educate the patient?
a) Always
b) Sometimes
c) Almost never
d) Never

11. Who educates the patients in your healthcare clinic?
a) Only you
b) A nurse
c) A pharmacist in a pharmacy
d) Nobody, the patient is given an educational leaflet 


\title{
Znanje ili neznanje o pravilnoj upotrebi inhalatora među lekarima u primarnoj zdravstvenoj zaštiti, Srbija
}

\author{
Marina B. Fišeković Kremić \\ Dom zdravlja "Novi Beograd", Beograd, Srbija
}

Uvod. U svakodnevnoj upotrebi većina pacijenata pravi greške u upotrebi inhalatora. Lekari primarne zdravstvene zaštite imaju važnu ulogu u sprečavanju nepravilne upotrebe inhalatora. Cilj ove studije je da se proceni nivo znanja o pravilnoj upotrebi inhalatora među lekarima primarne zdravstvene zaštite i način sticanja znanja o adekvatnoj tehnici inhalacije.

Metode. Ovo je studija preseka, sprovedena marta 2019. u Beogradu, Srbija. Uzorak su činili lekari koji rade u domovima zdravlja u Srbiji. Podaci su prikupljeni upitnikom. Rezultati su prikazani parametrima deskriptivne statistike. Razlika između dve posmatrane grupe i ostalih promenjivih testirana je Hi kvadrat testom. Podaci su analizirani SPSS 20.

Rezultati. Istraživanjem je obuhvaćeno 364 lekara primarne zdravstvene zaštite. Od ukupnog uzorka, 86,5\% su

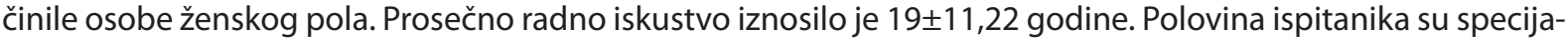
listi opšte medicine (53\%). Većina ispitanika znanje o pravilnoj upotrebi inhalatora stekla je na predavanjima i radionicama (50,3\%). Lekari su pokazali nezadovoljavajući nivo znanja.

Zaključak. Lekari primarne zdravstvene zaštite poseduju neadekvatna znanja i veštine o pravilnoj upotrebi inhalatora. Predavanja i radionice nisu dovoljan način edukacije lekara o pravilnoj upotrebi inhalatora.

Ključne reči: inhalatori, znanje, edukacija, opšta praksa 